\title{
Gillett-Swan Jenna and Coppock Vicki (Eds.) (2016). Children's Rights, Educational Research and the UNCRC: past, present and future. Oxford, UK: Symposium Books. 166 p. ISBN 978-1-873927-95-3
}

Reviewed by GordANA ČIŽMAN

The Convention on the Rights of the Child (hereinafter: the CRC) was signed and ratified by most countries in the shortest possible time. As a legal document, it had an extremely significant impact on national legislation and indirectly on the situation of children and their rights in the world. There is no doubt that it is merely a merit-based convention; today, we are much more aware of the situation of children, which has improved significantly throughout the world. It is true, however, almost thirty years after its enforcement, that children's rights are still and often violated and are often the subject of many research

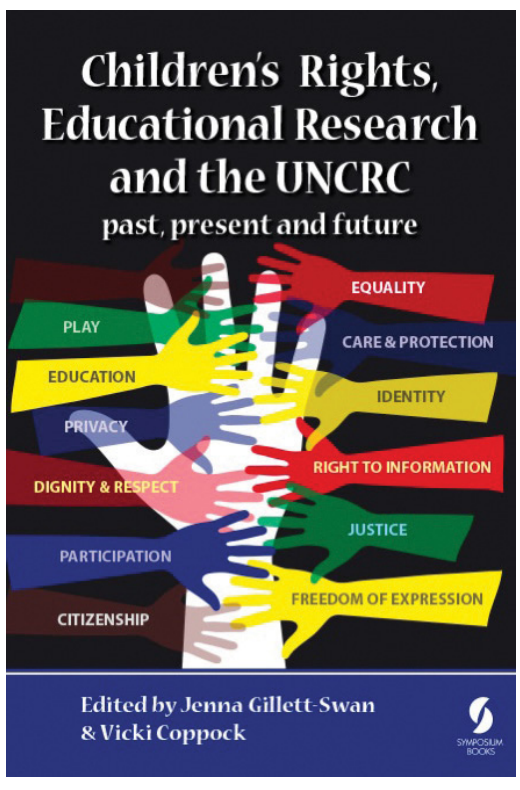
studies and debates in various professional circles, in politics, and in everyday discourse.

The book, edited by Jenna Gillett-Swan and Vicki Coppock, Children's Rights, Educational Research and the United Nations Convention on the Rights of the Child: Past, Present and Future, presents the contributions at the annual conference of European Research Associations, which was attended by experts from Australia, Finland, Portugal, Sweden, and the United Kingdom. Each of the seven chapters of the book focuses on various aspects of the rights of the child in the context of educational research and their current place in society and presents changes in the understanding of children's rights that have occurred since the adoption of the CRC to date. Among other things, the book presents a theoretical and historical overview of children's rights and the concept of childhood, the importance of human rights education and models of 
child participation, which offers an interesting reading, not only for researchers and pedagogical workers but for anyone interested in children's rights in general.

In the introductory chapter, the editors present the reasons for the publication of the book, its goal and the general conceptual framework of the book. They present three key topics that are discussed in the book, and which are also most often the subject of research and publications since the adoption of the CRC. These are the autonomous and participative role of the child as a new norm in educational policies and practices (understanding that a child is competent to represent him/herself), then the dichotomy of children's and parental rights (the right of parents to raise a child according to one's own beliefs and the right of the child to self-determination) and de-contextualisation of the rights of the child from the child's experiences in everyday life. The latter topic deals with the challenges of the so-called global children's rights industry (page 9), which reduces the child's rights to identifying the techniques such as standards, implementation, and control that dominate discussions on the content and meaning of children's rights. These topics are presented in the chapters of the book, and their contribution is primarily to show the diversity of understanding of children's rights and their place in educational programmes, as well as the diversity of educational contexts in which children's rights are being implemented.

In the first chapter, John I'Anson presents a historical overview of children's rights and the historical background of the connection between children's rights and research in education. The author analyses a series of key issues that have prevailed in research on children's rights in education, such as 'voice, 'cooperation', and 'ecological perspective' and analyses them from different aspects of children's rights. The author warns about different approaches and interpretations of children's rights and different practices in different cultural environments. He draws attention, in particular, to the approaches that separate children and their rights from certain cultural contexts and argues for the use of more nuanced interpretations of children, childhood and children's rights. I'Anson also draws attention to the content and meaning, as he calls it, 'neglected articles' (page 24) of the CRC and identifies shortcomings in the area of research in the field of children's rights and concludes the chapter with a short discussion on orientations for the future.

The next two chapters focus on educating children about their rights. Louise Gwenneth Phillips refers to Article 42 of the CRC which requires states to 'inform of the contents of the CRC both, children and adults', and presents a critical analysis of the different approaches to promoting CRCs through human 
rights education and draws attention to restrictions on their implementation. It also presents a number of international programmes and national initiatives, aimed at bringing CRC to the attention of children and presenting how this kind of education is conducted around the world. Regardless of all this, Phillips believes that the CRC is still relatively unknown among adults and children. The reasons for this are sought in the historical and contemporary conceptualisation of the child and childhood, and the solutions in the change of attitude towards children, teacher education and the constructive use of information technology. In her paper, Phillips clearly emphasises that the very existence of the $\mathrm{CRC}$ is unfortunately not sufficient to realise the rights of the child, and therefore addresses the adults with her initiative to recognise children as social agents who should know and understand their rights.

Nina Thelander's article points out the importance and contents of children's and young people's education on human rights. The author offers a discussion on the development of international and regional policies related to the right of the child to human rights education and what this learning means from a) knowledge, skills, b) values, attitudes and behaviours, and c) activities for the protection and promotion of human rights. In her contribution, she focuses on another international initiative - the World Program for Human Rights Education, which also represents the conceptual framework of its qualitative research on human rights education at two elementary schools in Sweden. To illustrate, she presents the experiences and examples of two teachers who, in their daily work, introduce human rights education to school, and thus also an insight into the challenges that they encounter in the implementation of these tasks.

In Chapter 4, Reetta Niemi, Kristiina Kumpulainen, and Lasse Lipponen represent examples of the realisation of children's participatory rights in everyday pedagogical practice in Finland, based on an action research study carried out at the elementary school there. The authors present three models of child participation (after Hart, Shier, and Lundy) and offer a discussion on how these models are reflected in the Finnish national curriculum and in pedagogical practice. In addition to an in-depth presentation of the field of child participation, the article also presents case descriptions that can be educational material for all who deal with children's rights at different levels and in different contexts.

In Chapter 5, Joana Lúcio and Fernando Ilídio Ferreira deal with the issue of children's rights in the context of social and economic instability in Portugal. Through the framework of the rights of the child to 'care, protection and participation', children's rights can be threatened in challenging economic times. In a survey among pre-primary teachers, they are exploring the issue of their role in the civil and political development of children and the willingness 
to implement approaches based on the realisation of rights and the impact of the social and economic crisis on children. They also discuss how the content of teacher education has changed with the introduction of the Bologna system at Portuguese universities, which has given priority to 'academic and didactic perspectives' (page 116) before a more humanistic approach, which is necessary for the realisation of children's rights.

In Chapter 6, Gordon Tait and Mallihai Tambyah present an interesting perspective and a critical analysis of the child's right to privacy, as defined in Article 16 of the CRC. Starting from the context of Australia, they present a comparison between CRC, the Australian legislation and practice. They thoroughly describe the idea of privacy as a social construct and the impact of this idea on children today. However, nowadays the child's privacy is increasingly shrinking due to social pressures of increasing control over children, the right to privacy and the right to protection may conflict, so it is necessary to look for ways to balance them. This is a great challenge, not only for parents, but also for the family, and for schools where the right to privacy is limited by physical supervision and the control of an ever-increasing amount of data. The author also deals with the legal protection of the child's right to privacy, which is not foreseen in the CRC. Nonetheless, they believe that the CRC is vital as an aspirational document and a symbolic lens through which it is also necessary to discuss the child's right to privacy.

The last chapter explores the future of children's rights and how technology or the digital world shapes the lives of children. Authors Jenna Gillett Swan and Vicki Coppock argue that the expansion of technology has helped children to express themselves and have access to various sources of information, that is, to the implementation of Articles 13 and 17 of the CRC. They represent how the scope of children's rights is changing with the increased use of technology and reflect on the benefits of digital technology, such as support for the education on children's rights, as well as on the weaknesses and the issue of security and the right to privacy and protection, which are greatly jeopardised by the expansion of digital media.

The book can be of interest to all those who are also interested in children's rights in general. It is recommended for all those who work in the field of education, especially because of its message on the importance of awareness of the education of children about their rights and their implementation in the field of education. The content of the book can serve as a learning example for the introduction of new practices in the education of children, as a starting point for educating pedagogical workers, as well as a reminder that human rights education does not take place only within the framework of education, 
but also in everyday life, in which adults by showing that we respect children's rights set example and act in an educational way. The application value of the book is also in a detailed description of the research and education research contexts in relation to the rights of the child, which can encourage research.

Although the editors predict that the monograph also offers a global perspective and presentation of diverse and extensive contexts, this prediction is premature and somewhat exaggerated. Given that almost all of the presented examples of research on children's rights were carried out in Europe, which is a historically, culturally, economically and politically specific space, the results would be difficult to apply to the environment beyond this geopolitical space. In order to at least partially achieve the aim, one would expect the book would round up with a more in-depth and analytical discussion in the final chapter, since the individual chapters are unconnected and, at the same time, contradictory. Otherwise, the monograph offers a pleasant reading, which again draws attention to the importance and value of knowing, respecting, and exercising the rights of the child. 